\title{
Scale-dependent habitat selection by a nearshore seabird, the marbled murrelet, in a highly dynamic upwelling system
}

\author{
Benjamin H. Becker ${ }^{1,2, *}$, Steven R. Beissinger ${ }^{1}$ \\ ${ }^{1}$ Division of Ecosystem Sciences, Department of Environmental Science, Policy \& Management, University of California, \\ Berkeley, California 94720-3110, USA
}

${ }^{2}$ Present address: Pacific Coast Science and Learning Center, Point Reyes National Seashore, Point Reyes Station, California 94956, USA

\begin{abstract}
We investigated daily and annual variation in the marine habitat selection of marbled murrelets Brachyramphus marmoratus (Alcidae) in the nearshore California Current System at scales of 10 to $100 \mathrm{~km}$ of coastline. We addressed 2 general questions: (1) how do murrelets select habitat while facing dramatic and often rapid variation in oceanographic conditions and prey availability; and (2) does selection vary between meso- $(10$ to $100 \mathrm{~km})$ and fine- $(<10 \mathrm{~km})$ scales. Marine transects were performed during 1999 and 2000 to survey murrelets and prey-fish schools, and to collect data on physical oceanography. We predicted that habitat selection would vary with upwelling intensity and prey availability: prey-aggregating mechanisms should be more important under low upwelling scenarios when cool, productive water is more limited, and murrelets should forage closer to nesting habitat when prey availability is high. This was generally the case, as murrelets selected cooler locations when upwelling was low and locations closer to nesting habitat when upwelling was high. Interactions among variables were important; murrelet habitat selection for prey and fronts changed among different sea surface temperatures (SSTs), distance to nesting habitat, upwelling intensity, and overall prey availability. Scale-dependent selection for prey patches (fish schools) and fronts occurred within larger-scale selection for SST or distance from nesting habitat. Additional scaledependent effects of prey availability were revealed by small-scale surveys in an area of high prey density. In this case, murrelets selected cool water (higher quality habitat) when prey availability was low and were associated with prey schools when prey availability was high. Additional large-scale surveys from 1996 to 2000 revealed that these patterns also manifested themselves on a longer temporal scale. Murrelets occurred farther from nesting flyways in years when spring upwelling was low and during the 1998 El Niño Southern Oscillation (ENSO) when local food webs were depressed and numerous other seabird species failed to reproduce.
\end{abstract}

KEY WORDS: Marbled murrelet - Brachyramphus marmoratus - Seabird - California Current · Habitat selection $\cdot$ Classification trees $\cdot$ Upwelling $\cdot$ El Niño Southern Oscillation

Resale or republication not permitted without written consent of the publisher

\section{INTRODUCTION}

The survival and reproductive success of seabirds depends on finding profitable foraging sites in a marine environment where prey density is generally low, patchy, and changing quickly in space and time (Russell et al. 1992, Bakun 1996, Gaston \& Jones 1998,
Hunt et al. 1998). Nevertheless, high quality foraging sites are often predictable due to recurrent oceanographic processes that aggregate or advect prey into a region (Ainley et al. 1996, Hunt et al. 1998, Russell et al. 1999). Water convergence aggregates lower trophic level organisms (phyto- and zooplankton) along horizontal (surface) or vertical (pycnocline) density fronts 
(Bakun 1996, Hunt 1997). Frontal structure can be developed by tidal forcing, upwelling, downwelling, vertical temperature stratification, interactions between currents and bathymetry, and eddies created by current interactions with islands and promontories (Schneider et al. 1990, Bakun 1996). Additionally, upwelling may increase prey availability by bringing deep prey to the surface (Hunt 1997).

Higher trophic level fishes, birds and mammals may congregate at predictable sites in response to heightened availability or density of prey resources due to aggregation by physical processes (Piatt 1990, Bakun 1996). The predictability of high quality foraging habitat, however, may vary with scale (Hunt et al. 1999). At the scale of $10 \mathrm{~s}$ to $100 \mathrm{~s}$ of kilometers (mesoscale), seabirds are often associated with in situ primary production or large-scale advection of prey, whereas at scales of less than $10 \mathrm{~km}$ (fine-scale), seabirds generally forage in areas with oceanographic features that tend to aggregate prey and primary production becomes less important. Thus, seabirds appear to make hierarchical decisions - first to find large-scale and then to locate small-scale habitat features that aggregate prey (Russell et al. 1992, Weimerskich et al. 1997, Nevitt \& Veit 1999, Fauchald et al. 2000). Cues that may help seabirds select profitable foraging habitat and then prey within that habitat include water temperatures (Ribic \& Ainley 1997), thermal fronts (Hoefer 2000), pycnocline depth (Ribic \& Ainley 1997), olfactory cues (Nevitt 1999), the presence of other birds (Lachmann et al. 2000), and the ability to visually locate prey (Gaston \& Jones 1998). During the breeding season, nesting seabirds have the additional energetic constraint of traveling between colonies and foraging sites (Hull et al. 2001).

We investigated the influence of oceanography and prey availability on the habitat selection of a nearshore seabird, the marbled murrelet Brachyramphus marmoratus (Alcidae), during the breeding season in central California (see Fig. 1). Murrelets forage primarily within 1 to $2 \mathrm{~km}$ from shore and nest in mature forests from Alaska to Central California (Ralph et al. 1995, Becker et al. 1997). They engage in biparental incubation and feeding of nestlings, and most birds are probably old enough to be potential breeders (Beissinger 1995, Beissinger \& Nur 1997). In addition to the constraints that colonial nesting seabirds face, marbled murrelets travel up to $90 \mathrm{~km}$ inland over habitat that is unsuitable for foraging to nest in old-growth trees (Hamer 1995). From energetics, risk and time perspectives, commuting may limit nesting habitat availability (Hull et al. 2001), since the adequate foraging habitat is at least as far away as the distance between the ocean and inland nesting habitat. Subsequently, commuting may also restrict nesting murrelets to a smaller marine foraging range than would be predicted by foraging mode (i.e. surface or sub-surface feeder), body size or wing loading (Gaston \& Jones 1998, Hull et al. 2001).

During the breeding season, murrelets appear to select upwelled or well-mixed waters near nesting sites (Ainley et al. 1995a, Lougheed 2000). However, the spatial and temporal resolution of previous studies limits inferences regarding the dynamics of murrelet habitat selection under both short-term (weekly) and long-term (annual) changes in prey availability, ocean conditions, and spatial scale (Ostrand et al. 1998).

We investigated the processes that marbled murrelets use to select marine habitat at several scales in the California Current System during the breeding season. We assumed that murrelets selected habitat primarily as a function of the competing constraints of minimizing energy expenditure by seeking food near their nesting habitat, while maximizing access to prey (Orians \& Pearson 1979, Verner et al. 1986, Hunt et al. 1999). First, during periods of reduced upwelling, prey aggregation at fronts and cooler, more productive waters would be less common (Bakun 1996). Consequently, we hypothesized that murrelets would select the limited regions of cool and potentially more productive waters in which to forage, and we predicted that lower SSTs would explain much of the variance in murrelet distribution under low upwelling conditions. Second, when prey availability was relatively high, we predicted that murrelets would forage closer to their nesting habitat, reducing the importance of SST in explaining murrelet distributions. Third, we predicted that there would be hierarchical, scale-dependent habitat selection: fine-scale habitat features, such as fish schools, fronts, and stratified water would interact with mesoscale parameters, such as SSTs and distance to nesting habitat, to determine murrelet distributions (Weimerskirch et al. 1997, Nevitt \& Veit 1999). Finally, we investigated how selection changed across spatial scales varying from 10 to $100 \mathrm{~km}$ and across temporal scales varying from weeks to years.

\section{MATERIALS AND METHODS}

We studied a semi-isolated population of approximately 500 to 700 marbled murrelets Brachyramphus marmoratus (Alcidae) (Becker et al. 1997, Peery et al. 2001) in central California between Half Moon Bay and Soquel Point, near Monterey Bay, California, USA (Fig. 1). This population is at the southernmost range of the murrelet's breeding distribution, which is probably limited by availability of old-growth forest habitat for nesting (Ralph et al. 1995). Breeding season (April to August) radio-telemetry studies of both breeding and 
non-breeding murrelets found that they do not forage at night (Peery et al. 2001), so diurnal samples of their marine distribution should primarily reflect habitat choice based on strategies for acquiring prey. Simultaneous bird-prey-oceanographic surveys were conducted at both the mesoscale $(10$ to $100 \mathrm{~km})$ and the fine scale $(<10 \mathrm{~km})$ to determine the response of Marbled Murrelet habitat selection to variation in prey availability and oceanography.

At-sea surveys. Mesoscale selection: Mesoscale transects were randomly placed to cover the area 200 to $2500 \mathrm{~m}$ from shore between Half Moon Bay and Soquel Point (Fig. 1). Transects traveled from north to south in a zig-zag pattern at approximately $30^{\circ}$ from parallel to shore. Because murrelet density is higher nearshore, the transects sampled the region from 200 to $1350 \mathrm{~m}$ approximately 5 times as much as the area from 1350 to $2500 \mathrm{~m}$ (Fig. 1).

From June to August in 1999 and 2000, 14 surveys were performed along approximately $100 \mathrm{~km}$ of coastline. Navigation

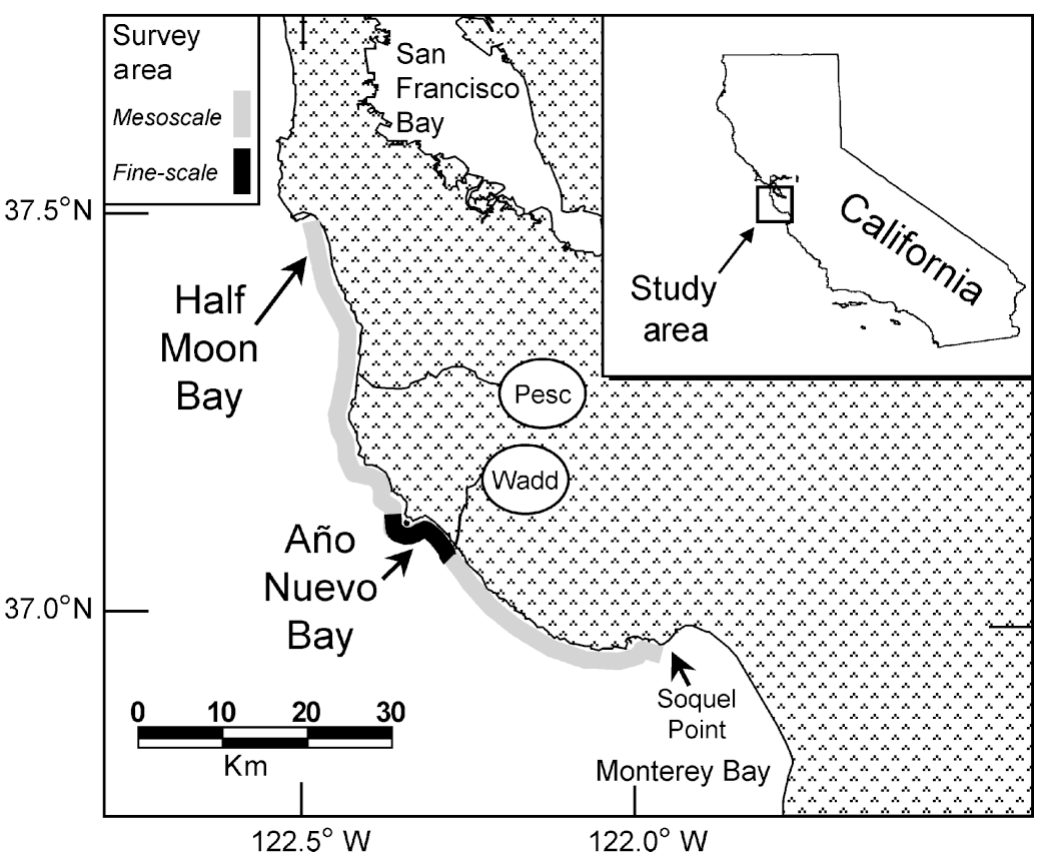

Fig. 1. Central California study area. Primary inland flyways for murrelets Brachyramphus marmoratus are Pescadero (Pesc) and Waddell Creek (Wadd) watersheds and feature locations were recorded with differential GPS in 1999, and uncorrupted (i.e. no selective availability) GPS in 2000. Each survey began $\sim 1 \mathrm{~km}$ south of Princeton Harbor in Half Moon Bay (Fig. 1) after randomizing distance from shore between 200 and $1350 \mathrm{~m}$, direction of travel (towards or away from shore), and small or large zig-zag (out to $1350 \mathrm{~m}$ or $2500 \mathrm{~m}$ from shore, respectively). Surveys were performed from a $4.5 \mathrm{~m}$ vessel traveling at $\sim 20 \mathrm{~km} \mathrm{~h}^{-1}$ and generally began 30 min after dawn. Murrelets are often found directly offshore from nesting flyways at dawn (Ralph et al. 1995), so we surveyed areas offshore of flyways 3 to $5 \mathrm{~h}$ after dawn to minimize bias due to birds recently arriving from inland flights. Each survey used 2 observers, who were each responsible for recording birds on different sides of the boat using distance sampling methodology (Buckland et al. 1993, Becker et al. 1997), and a driver who navigated with GPS and operated the sonar. We also recorded 2 common nearshore alcids: common murres Uria aalge and pigeon guillemots Cepphus columba, when they were within $50 \mathrm{~m}$ of either side of the vessel. Flying birds were excluded from analyses.

We used a downsounding sonar $(200 \mathrm{kHz}$ Interphase Technologies) for prey school assessment (Safina \& Burger 1988, Piatt 1990). Gain (sonar sensitivity) was constant for all surveys and the top $2 \mathrm{~m}$ of the water column was masked due to surface turbulence. Familiarity with the area and knowledge of kelp bed loca-

tions generally allowed us to confidently separate kelp from fish signatures. If a signal was suspected to be kelp or air bubbles, it was removed from the analyses. Fish schools were assigned a GPS location and time. Prey fishes breaking the ocean surface but not registering on the sonar were also recorded. To ground truth the sonar system, we performed 50 random casts with a 6-hook herring jig over negative and positive sonar detections. Jigs were cast 2 times per test and slowly lifted $\left(\sim 1 \mathrm{~m} \mathrm{~s}^{-1}\right)$ from the ocean floor to the surface (water depths $=13$ to $20 \mathrm{~m}$ ). Thirtythree pairs of casts were done on top of fish schools detected by the sonar and each pair of casts caught at least 1 fish. Seventeen pairs of casts were done in waters where no fish were detected by the sonar, and all of these jig casts caught no fish. Fish caught included Pacific sardine Sardinops sagax, northern anchovy Engraulis mordax, Pacific herring Clupea harengus, and Pacific sanddabs Citharichthys sordidus, which are all known prey of murrelets (Burkett 1995). These results indicate that the sonar was extremely reliable for identifying presence or absence of prey fish schools, but not for species composition.

Midwater fish trawls during April 2000, November 2001, and July 2002 in Año Nuevo Bay (Fig. 1) using an $5 \times 2 \mathrm{~m}$ otter trawl with $30 \mathrm{~mm}$ mesh primarily caught night smelt Spirinchus starskii, white croaker Genyonemus lineatus, northern anchovy, and market squid Loligo opalescens (L. A. Henkel \& J. T. Harvey unpubl. 
data). Most captured prey items were 30 to $60 \mathrm{~mm}$, which is within the range of known murrelet prey items (Burkett 1995). During the July 2002 trawls, juvenile black, copper and shortbelly rockfish (Sebastes melanops, S. caurinus, and S. jordani, respectively); greenling species (Hexagrammos spp.); and speckled sanddabs Citharichthys stigmaeus were also present in moderate numbers, but there were no anchovy or squid at this time. Likewise, annual spring trawls conducted by the National Marine Fisheries Service off central California typically included juvenile rockfish, Pacific sardine, northern anchovy, market squid Loligo opalescens, and euphausiids Euphausia pacifica and Thysanoessa spinifera) (S. Ralston, National Marine Fisheries Service, unpubl. data), which are all eaten by marbled murrelets (Burkett 1995). The $200 \mathrm{kHz}$ sonar should also detect squid and euphausiid swarms (Hunt et al. 1998). However, the only invertebrates detected were dense swarms of moon jellyfish Aurelia aurita that were easily distinguished from fishes. Thus, due to the high reliability of the sonar and the length of prey fishes caught in trawls, it is likely that most of the fish schools detected by the sonar contained individuals suitable for murrelet consumption.

Surveys paused at $\sim 2 \mathrm{~km}$ intervals to record water temperature and salinity at the ocean surface and at depths of 5,10 and $15 \mathrm{~m}$. During the analyses, we considered sea surface temperature (SST) as the value at $5 \mathrm{~m}$ below the surface because it had a slightly higher correlation with murrelet presence than true SST ( $\mathrm{r}=$ 0.40 vs. $r=0.37$, $d f=189$, all $p<0.001$ ). Also, temperatures directly at the sea surface $(<2 \mathrm{~m})$ may represent localized, ephemeral conditions of surface heating or low vertical mixing rather than the status of local upwelling conditions (Sakuma et al. 2002). Temperature and salinity were recorded with a YSI SCT-50 temperature and conductivity probe with a resolution of $0.1^{\circ} \mathrm{C}$ and $0.1 \mathrm{ppt}$, respectively. Bathymetry (water depth) in the study area was derived from 315 randomly located sonar soundings interpolated into a $100 \mathrm{~m}$ grid using splines in a Geographic Information System, GIS (Environmental Systems Research Institute 1998). We used the closest available Bakun upwelling index (UI) calculation from $36^{\circ} \mathrm{N}, 122^{\circ} \mathrm{W}$ (Pacific Fisheries Environmental Laboratory; available at www.pfeg.noaa.gov). The UI is expressed in terms of cubic meters of water upwelled per second per $100 \mathrm{~km}$ of coastline $\left(\mathrm{m}^{3} \mathrm{~s}^{-1} 100 \mathrm{~m}\right)$ and is a function of equatorward wind speed (Bakun 1996).

Fine-scale selection: Similar survey methodology was used for fine-scale surveys $(\mathrm{N}=19)$ conducted to compare fine-scale selection processes in an area of consistently high prey density with the factors affecting mesoscale habitat choice within the much larger study area. These surveys were confined to Año Nuevo Bay (Fig. 1) from June to August 1998 to 2000. Transects were placed parallel to shore at 400, 900, 1400 and $2400 \mathrm{~m}$ from shore. Each transect was $10 \mathrm{~km}$ long, and data were pooled for all transects on a given survey day.

Temporal selection: To detect annual variation in the along-shore distribution of murrelets, we also performed $90 \mathrm{~km}$-long weekly surveys from Half Moon Bay to Soquel Point (Fig. 1) during June to August 1996 to 2000. Unlike the zig-zag coupled bird-prey-oceanic surveys of 1999 to 2000, these surveys paralleled the coast at 400 to $500 \mathrm{~m}$ from shore and did not record oceanographic or prey data. They were used to investigate the relationship between upwelling intensity and the mean distance of murrelets from nesting flyways.

Analyses. To investigate the effects of upwelling on potential thermal surface fronts, we modeled the relationship between variation in SST and the upwelling index using Spearman rank correlation coefficients on 30 transects (both zig-zag and parallel to shore) completed from Half Moon Bay to Soquel Point from 1998 to 2000. The upwelling index was the mean of the survey day and of the previous $2 \mathrm{~d}$. Variation in SST was measured by calculating the change in SST km-1 transect for each survey day and using the coefficient of variation as an index of the number and magnitude of horizontal surface fronts present.

For each survey, we created a continuous $100 \mathrm{~m}$ cell surface of SST in a GIS using spline interpolation with ArcView 3.2 (Environmental Systems Research Institute 1998). Daily SST anomalies were calculated by interpolating a tension spline surface between temperature data points and subtracting these values from the mean SST for the entire study area on any given survey day. Surface fronts were calculated as the slope of water temperatures across the water surface between adjacent cells. Vertical water stratification was calculated as the difference between water temperature at the surface and at $5 \mathrm{~m}$. All other independent variables (i.e. nest distance, fish schools, and the number of common murres Uria aalge and pigeon guillemots Cepphus columba) and the binary dependent variable of presence or absence of marbled murrelet clusters were also gridded into GIS layers by survey day. Independent variables were measured within a $200 \mathrm{~m}$ radius around each cluster of murrelets and an equal number of random non-occupied points along the transect line. We chose a $200 \mathrm{~m}$ radius because murrelets were detected up to $150 \mathrm{~m}$ from the vessel (although > $85 \%$ of detections were within $50 \mathrm{~m}$ ) and fish schools were only detected directly under the vessel; therefore, we could not resolve spatial relationships of less than $150 \mathrm{~m}$. This limitation also had the effect of failing 
to detect some fish schools that may have been associated with birds. Thus, model results probably underestimate the importance and occurrence of fish schools. The number of fish schools, common murres and pigeon guillemots were summed within the $200 \mathrm{~m}$ radius while continuous variables such as SST and water depth were calculated as the mean value of cells within the radius. Effectively, the sonar only detects fish schools along the transect line, making the area summed by this analysis $200 \mathrm{~m}$ long and only several meters wide. Similarly, murres and guillemots were only surveyed to $50 \mathrm{~m}$ on either side of the transect line, making the summed area $200 \mathrm{~m}$ long and $100 \mathrm{~m}$ wide. Surface fronts were recorded as the maximum value within the $200 \mathrm{~m}$ radius, and distance to nesting habitat was recorded as the smallest value. Since $>99 \%$ of murrelet detections for all survey types during this study were in water less than $25 \mathrm{~m}$ deep, we only considered murrelets and random comparison points in depths of this range. This had the effect of reducing the importance of water depth in explaining murrelet distribution, but it limited the study to potential marine habitat. Distance to nest flyways was calculated as the shortest over-water flight path to either of the 2 primary inland flyways used to reach the nesting habitat-Pescadero and Waddell Creek watersheds (Fig. 1).

SST and distance to nesting habitat were moderately correlated $(\mathrm{r}=0.50, \mathrm{df}=229, \mathrm{p}<0.001)$, but inspection of scatterplots indicated that much of the correlation was due to the high SSTs that typically occur in northern Monterey Bay. Since we were interested in the interactions and relative effects of SST and nesting distance, we eliminated all samples that had an SST anomaly greater than $2^{\circ} \mathrm{C}(\mathrm{n}=40)$, many of which were near Monterey Bay, which is far from the nesting flyways. This lowered the SST distance to nest flyway correlation to $\mathrm{r}=0.28(\mathrm{df}=189, \mathrm{p}<0.01)$, which should allow each covariate to function relatively independently in statistical models. The relationship between the upwelling index and horizontal surface fronts was determined by the correlation of the upwelling index with the coefficient of variation (CV) in SST along the transect lines.

Probability plots showed that all continuous covariates were approximately normal except distance to nest, which was subsequently square-root transformed to induce normality. We examined habitat selection using both traditional logistic regression models and the more recently developed classification trees (Becker 2001). However, because of the close agreement between logistic regression and classification tree models (De'ath \& Fabricius 2000, Becker 2001) and the straightforward interpretation of nested interactions, we only report the classification tree results here. Detailed results and a comparison of the methods can be found in Becker (2001).

Classification tree models (SPSS 1998, De'ath \& Fabricius 2000) were built with the presence or absence of marbled murrelets as the dependent variable. We used the Gini index to select the most parsimonious classification tree models (De'ath \& Fabricius 2000). The Gini index takes the form $1-\sum c^{2}$, where $c$ is the proportion of occupied or non-occupied points. This index minimizes within-group diversity of the dependent variable (presence or absence of marbled murrelet clusters) by grouping it within nested interactions of the covariates that best explain the dependent variable. To avoid overly complex models, variables were required to explain at least $4 \%$ (proportional reduction in error $[\mathrm{PRE}] \geq 0.04$ ) of total model variance to be included in the final model. Classification tree models were built with a random subsample of $60 \%$ of the dataset and then cross-validated using the remaining $40 \%$ of the data. Model fit is reported in 2 ways. First, we use PRE, which is analogous to $\mathrm{r}^{2}$ in regression models (SPSS 1998). PRE is reported for both the entire model and individual variables. Second, we report the cross-classification rate success for the remaining $40 \%$ of data excluded from the model. Results are reported with classification accuracy and the number of clusters used to build and test the models.

Our goal was to identify if upwelling intensity and fish school abundance had significant interactions with the other covariates. Thus, prior to the analyses, the 14 surveys were grouped into 4 unique combinations of low or high upwelling and low or high prey availability. Low or high upwelling and prey availability categories were determined by evenly splitting the upwelling and fish school data into the 7 lowest and 7 highest values. The number of fish schools detected per survey ranged from 5 to 105 . Surveys with less than 35 fish schools detected were classified as low prey availability and those with 35 or more detections were classified as high prey availability. Thus, models were built for surveys with low upwelling and low prey availability ( $\mathrm{n}=4$ surveys), low upwelling and high prey availability ( $\mathrm{n}=2$ surveys), high upwelling and low prey availability ( $\mathrm{n}=4$ surveys), and high upwelling and high prey availability ( $\mathrm{n}=4$ surveys). Each year (1999 and 2000) was represented at least once in each of the 4 categories. For brevity, we refer to these scenarios as LL, LH, HL, and $\mathrm{HH}$, where the first letter represents low or high ( $\mathrm{L}$ or $\mathrm{H}$ ) upwelling and the second letter represents low or high ( $\mathrm{L}$ or $\mathrm{H}$ ) prey availability.

Statistical analyses were done using Systat 8.0 (SPSS 1998) and JMP 4.0 (SAS Institute 2000). All classification tree nodes are significant at $\mathrm{p} \leq 0.05$. 


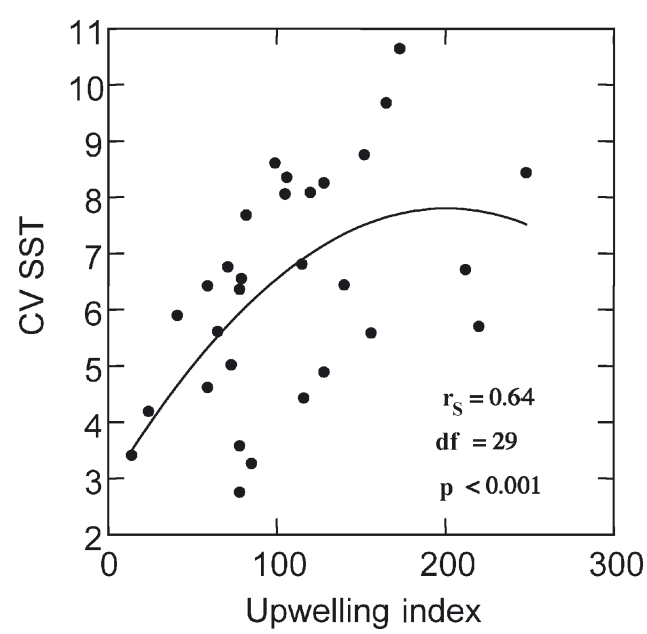

Fig. 2. Relationship between daily coefficient of variation (CV) in sea surface temperature (SST) and mean upwelling index for $48 \mathrm{~h}$ prior to days when mesoscale (both zig-zag and linear) surveys were conducted

\section{RESULTS}

\section{Univariate, mesoscale habitat selection}

The presence of murrelets was negatively correlated with depth, distance from nest flyways and water temperature (Table 1). Murrelets were positively correlated with prey fish schools and were not significantly correlated with water stratification, fronts, common murres or pigeon guillemots. When we only consider murrelets within $25 \mathrm{~m}$ of the boat, the correlation between murrelets and fish schools increases from $\mathrm{r}_{\mathrm{S}}=$ $0.29(\mathrm{n}=190)$ to $r_{S}=0.46(\mathrm{n}=78)$. Independent variables were generally uncorrelated or had low correlation (all $r_{S}<0.29$ ). However, SST was moderately correlated $\left(r_{S}=0.28\right)$ with distance to nesting habitat flyways (Table 1). Finally, fish schools were more likely to be found in shallower waters (Table 1).

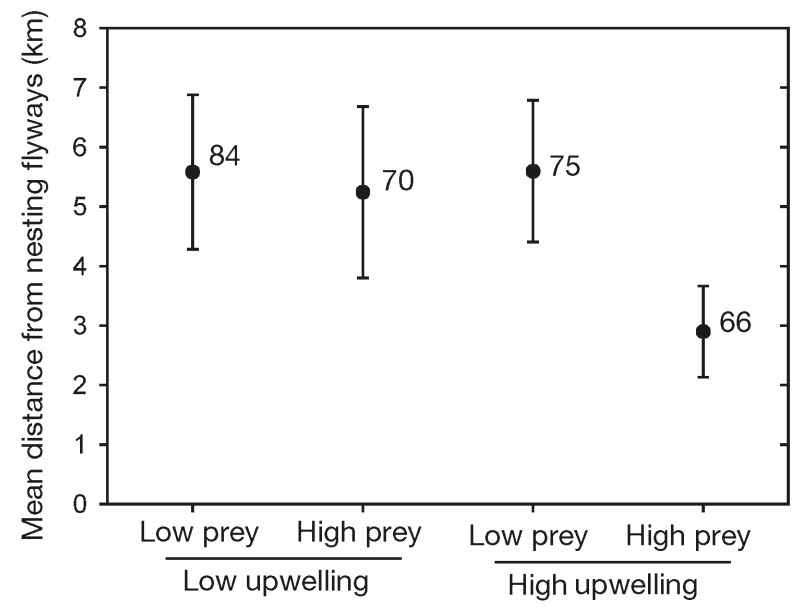

Fig. 3. Mean ( $\pm 1 \mathrm{SD}$ ) distance of murrelets from nesting flyways during low and high upwelling and prey availability. Data from mesoscale surveys

The variation in SST increased with increasing upwelling index, indicating more frontal activity during higher upwelling (Fig. 2). A 2-way ANOVA found that upwelling intensity $\left(F_{291,1}=4.69, \mathrm{p}<0.04\right)$, prey availability $\left(F_{291,1}=7.46, \mathrm{p}<0.01\right)$, and the interaction $\left(F_{291,1}=4.77, \mathrm{p}<0.03\right)$ had a significant effect on the distance of murrelets from nesting flyways. These effects were entirely due to the effect of high upwelling and high prey availability $(\mathrm{HH})$ conditions, during which murrelets were significantly closer to the nesting habitat than during the other 3 scenarios (Fig. 3) (Bonferroni adjustment, all p < 0.02).

\section{Mesoscale habitat selection}

Classification trees typically selected significant variables that were similar to the results of logistic regression models, but interactions were much easier to interpret. Model fits (PRE) ranged from 0.62 to 0.78

Table 1. Univariate means \pm SD and Spearman rank correlations between variables used in classification tree models. Rank correlations used because several variables were binary or not continuous (murrelets, fish schools, common murres, and pigeon guillemots). $\mathrm{N}=156$ occupied and 134 random locations. p-values are Bonferroni-adjusted for multiple comparisons. SST: sea surface temperature; bold-face indicates significance $\left({ }^{*} p<0.01 ;{ }^{* *} p<0.001\right)$

\begin{tabular}{|c|c|c|c|c|c|c|c|c|c|c|}
\hline Variable & Mean occupied & Mean random & Murrelet & Depth & Stratification & Fronts & Nest & SST & Fish & Murres \\
\hline Depth (m) & $12.3 \pm 4.0$ & $14.2 \pm 3.9$ & $-0.23^{* *}$ & - & & & & & & \\
\hline Stratification $\left({ }^{\circ} \mathrm{C}\right)$ & $0.7 \pm 0.5$ & $0.8 \pm 0.6$ & -0.14 & 0.07 & - & & & & & \\
\hline Fronts (slope) & $0.02 \pm 0.01$ & $0.02 \pm 0.01$ & -0.12 & -0.08 & $0.20^{*}$ & - & & & & \\
\hline Nest distance (m) & $4204 \pm 800$ & $10516 \pm 1481$ & $-0.49^{* *}$ & 0.06 & 0.18 & -0.03 & - & & & \\
\hline SST anomaly $\left({ }^{\circ} \mathrm{C}\right)$ & $0.4 \pm 0.5$ & $0.8 \pm 0.6$ & $-0.40^{* *}$ & 0.08 & -0.09 & 0.07 & $0.28^{* *}$ & - & & \\
\hline Fish schools & $0.5 \pm 0.7$ & $0.1 \pm 0.4$ & $0.29^{* *}$ & $-0.23^{*}$ & -0.01 & -0.08 & -0.10 & -0.03 & - & \\
\hline Common murres & $0.2 \pm 0.4$ & $0.3 \pm 0.4$ & -0.07 & 0.03 & -0.07 & 0.00 & 0.10 & 0.12 & 0.03 & - \\
\hline Pigeon guillemots & $0.1 \pm 0.3$ & $0.1 \pm 0.3$ & -0.04 & 0.00 & -0.04 & -0.09 & 0.05 & 0.04 & -0.05 & -0.05 \\
\hline
\end{tabular}


(A) LL: Classification $=0.84(25), 0.71(35)$

PRE $=0.78$

Low upwelling

Low prey
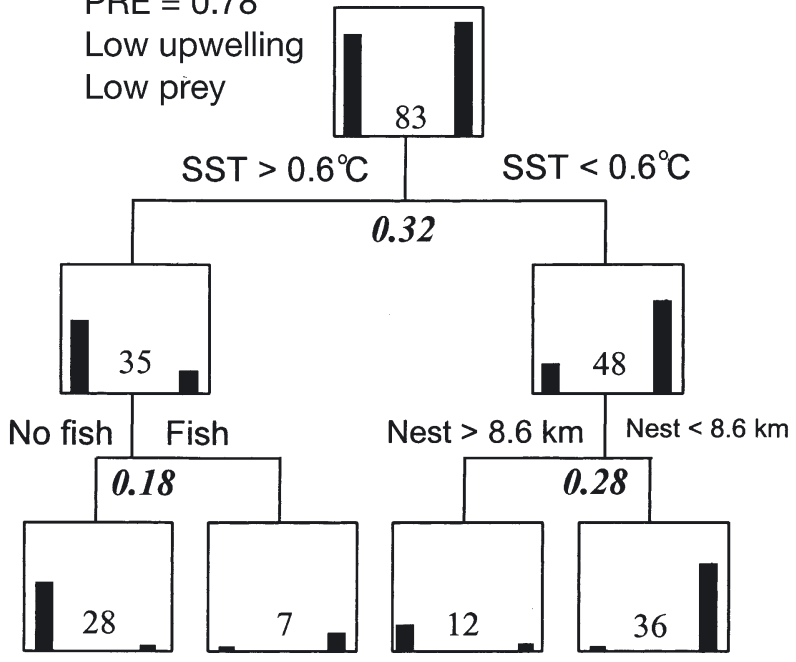

(B) LH: Classification $=0.83(30), 0.91(31)$

PRE $=0.68$

Low upwelling

High prey

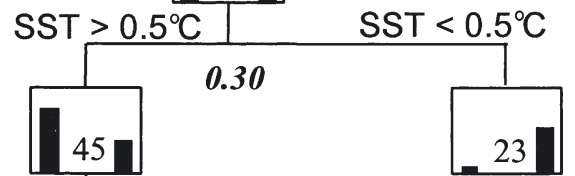

Nest $>7.5 \mathrm{~km} \quad$ Nest $<7.5 \mathrm{~km}$

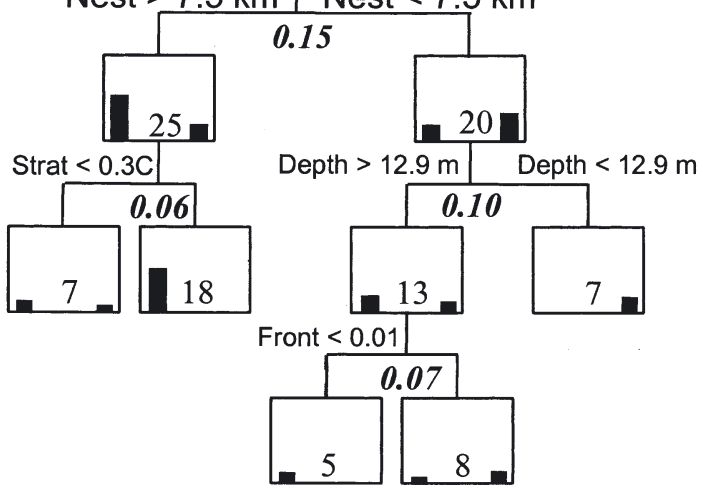

Fig. 4. Classification trees for at-sea mesoscale distribution during: (A) low upwelling and low prey availability (Model 1), and (B) low upwelling and high prey availability. Trees begin at top with all random (unoccupied) and occupied sample points, and cascade down with new distributions of random and occupied points as a function of independent variables. Bars on left side of each box represent random unoccupied points and bars on right side represent marbled murrelet clusters; height of bars is proportional to sum of random or occupied sample points; number inside each box is the sum of both bars. Italicized value below each division is proportional reduction in error (PRE) explained by each division. Classification accuracy is proportion (number) of absent and present clusters correctly classified using data excluded from model building. SST represents ${ }^{\circ} \mathrm{C}$ anomaly from mean of all SST measurements on a particular survey day. See 'Materials and methods' for explanations of other variables. Strat: stratification

(A) HL: Classification $=0.75(20), 0.69(29)$

PRE $=0.62$

High upwelling

Low prey

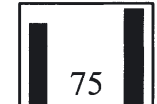

Nest $>7.7 \mathrm{~km} \mid$ Nest $<7.7 \mathrm{~km}$

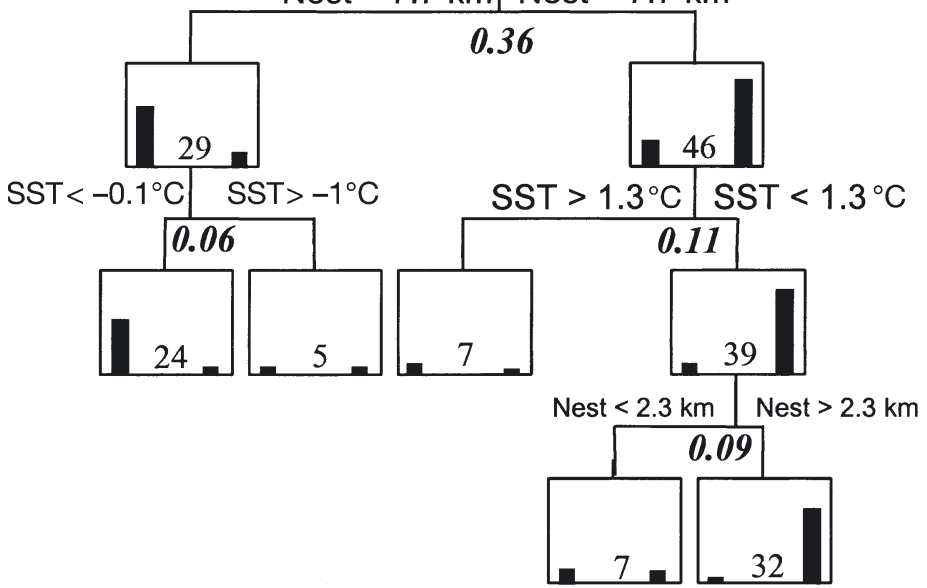

(B) $\mathrm{HH}$ : Classification $=1.00(24), 0.74(31)$

PRE $=0.74$

High upwelling

High prey

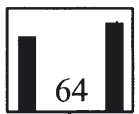

Nest $>5.6 \mathrm{~km} \quad$ Nest $<5.6 \mathrm{~km}$
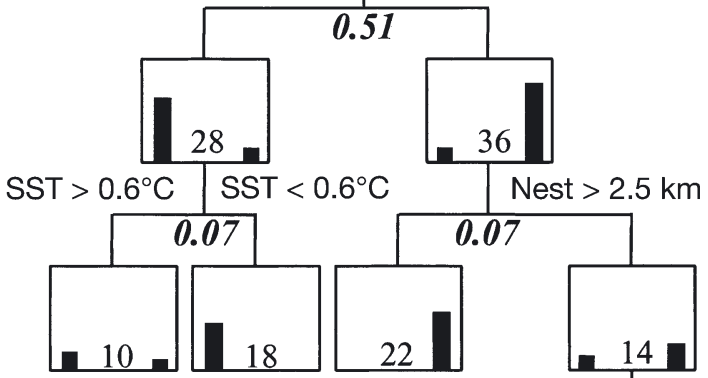

Nest $<3.7 \mathrm{~km}$

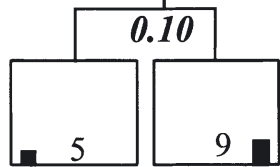

Fig. 5. Classification trees showing mesoscale selection during (A) high upwelling and low prey availability, and (B) high upwelling and high prey availability. Further details as in Fig. 4 
among the 4 models, and cross-validation (classification) accuracy for presence or absence ranged from 0.69 to 1.00 when tested with the remaining $40 \%$ of the data not used to build the models (Figs. 4 \& 5).

When upwelling was low, SST explained the most variation in murrelet distribution (Fig. 4). Conversely, distance to nesting habitat explained most variation during high upwelling (Fig. 5). Regardless of upwelling and prey availability, SST or nesting distance always explained the most model variation. Associations with prey fish schools were only significant under conditions of low upwelling and low prey availability (LL), and then only when murrelets were in warmer waters. Fronts were only important when upwelling was low and prey availability was high (LH), and in this case only for murrelets in warmer, deeper waters near the nesting habitat (Fig. 4B). Under these condi-

(A) LL: Classification $=0.87(23), 0.60(20)$

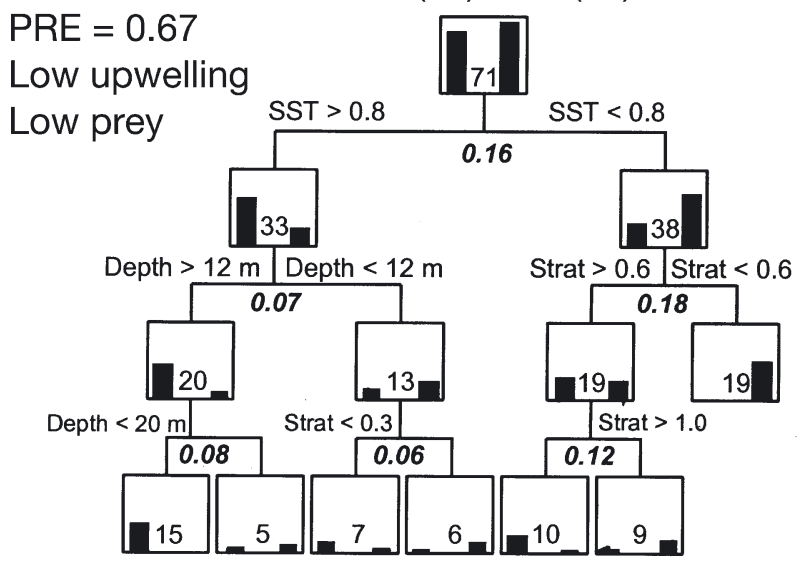

(C) HL: Classification $=0.89(35), 0.60(35)$

$$
\text { PRE }=0.45
$$

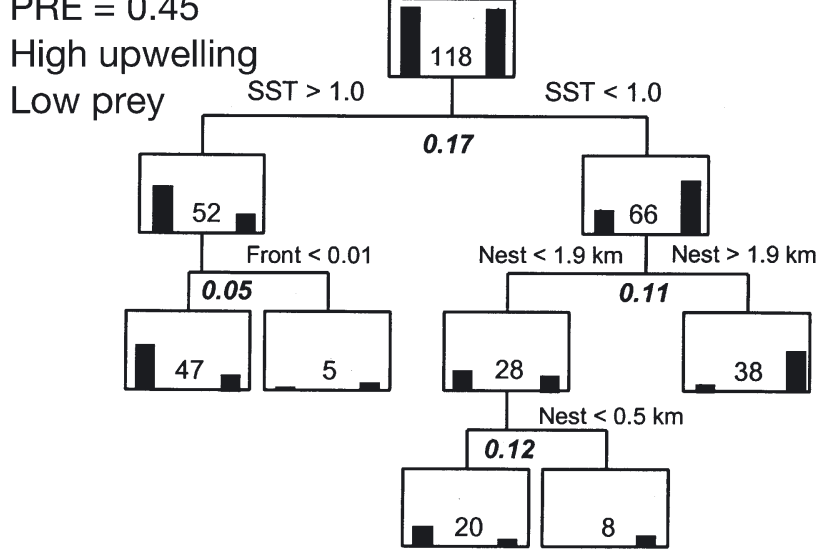

tions (LH), murrelets were found in unstratified, warm waters far from the nesting habitat. However, this distance was not farther than under LL and HL conditions.

\section{Fine-scale habitat selection in area of high prey density}

Fine-scale surveys in Año Nuevo Bay also showed a strong influence of upwelling and prey availability on murrelet habitat selection. Murrelets were highly associated with fish schools when prey availability was high, with fish schools explaining 0.27 and 0.21 of variance during low and high upwelling, respectively (Fig. 6B,D). Conversely, during low prey availability, SST explained most variation and fish schools were unimportant (Fig. 6A,C).
(B) LH: Classification $=0.84(43), 0.77(43)$

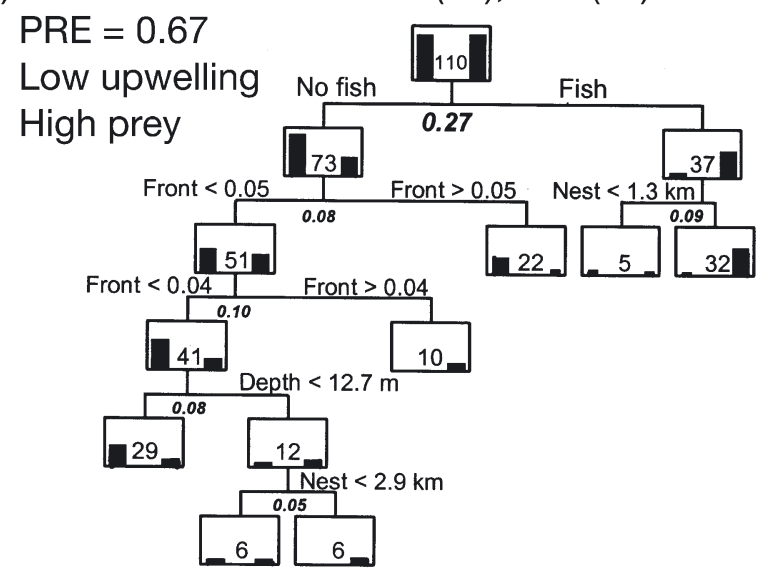

(D) $\mathrm{HH}$ : Classification $=0.83(23), 0.81(21)$

PRE $=0.60$

High upwelling

High prey

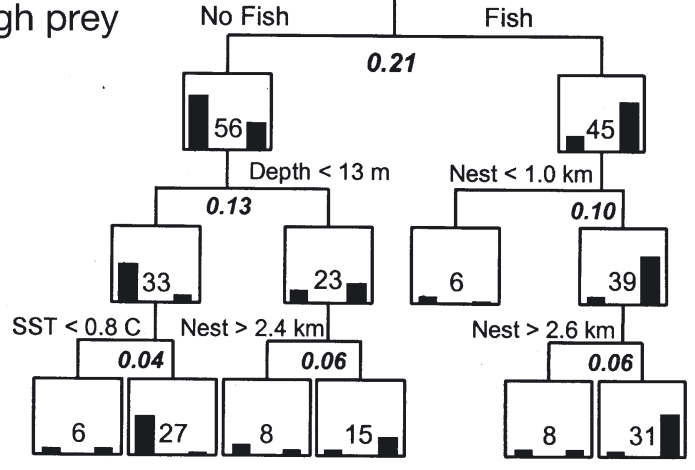

Fig. 6. Classification trees for fine-scale habitat selection in Año Nuevo Bay during (A) low upwelling and low prey availability, (B) low upwelling and high prey availability, (C) high upwelling and low prey availability, and (D) high upwelling and high prey availability. Further details as in Fig. 4 

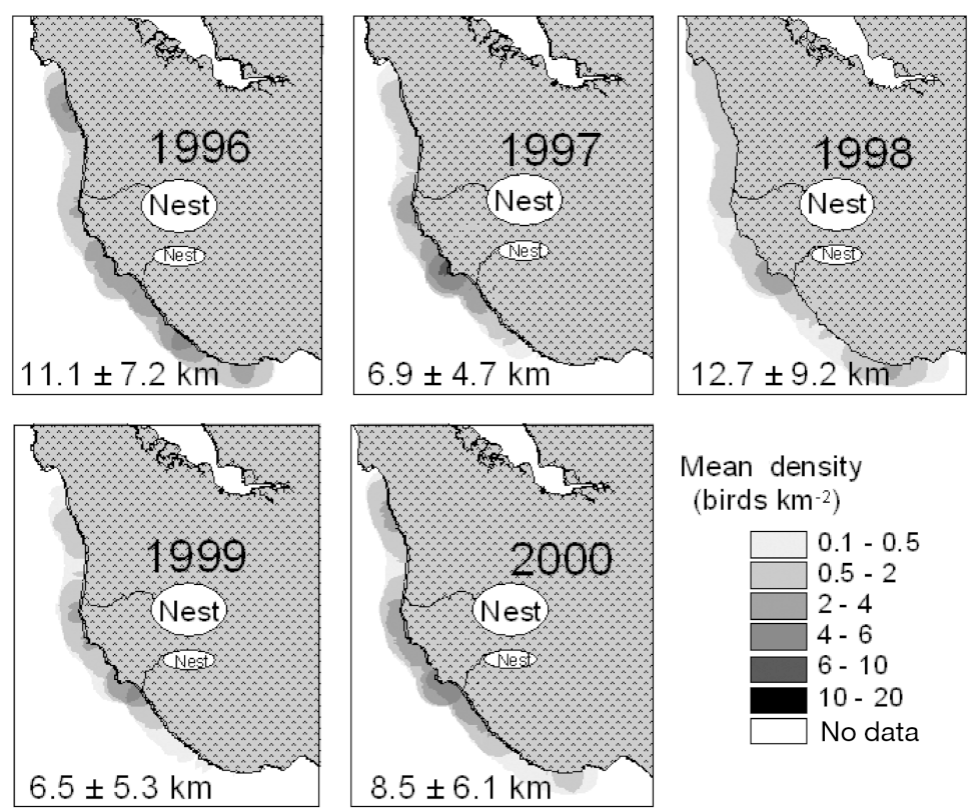

upwelling. In addition to having the lowest upwelling anomaly, 1998 was also an ENSO year with warm water conditions and decreased prey availability (Becker 2001).

\section{DISCUSSION}

Seabirds in the California Current System often change foraging locations and strategies in response to annual variation in upwelling, water temperatures and subsequent prey availability. They may seek out locations farther from nesting habitat, or abandon nests altogether in poor prey years (Ainley et al. 1995b). Previous studies, however, generally considered only interannual or interseasonal variation, and were conducted farther offshore $(>8 \mathrm{~km})$ over the continental shelf or beyond the shelf-break (Ainley \& Boekelheide 1990). Furthermore, it has been suggested that prey consumed by nearshore predators that forage inshore of the California Current proper are less affected by oceanographic variability (Ainley 1990). In addition to upwelling due to Ekman pumping, however, interactions of tides and currents with headlands (Rosenfeld et al. 1994) and

Average cross-classification rates were very good for predicting absence of murrelets for all the upwelling and prey availability scenarios, ranging from 0.83 to 0.89 . However, classification rate for presence of murrelets was generally poor during conditions of low prey availability (both $=0.60$ : Fig. 6A,C), and were moderate when prey availability was high $(0.77$ and 0.81: Fig. 6B,D).

\section{Temporal variation in habitat selection}

Murrelet distribution along the $\sim 100 \mathrm{~km}$ shoreline varied greatly among years; however, those areas directly offshore from the 2 nesting regions consistently had the highest murrelet densities (Fig. 7). The average distance of birds from nesting flyways was greatest in 1996 and 1998, with birds more evenly distributed throughout the region compared to 1997 , 1999, and 2000. ANOVA revealed that mean distance from nesting flyways differed among all years $\left(F_{4,2494}=\right.$ 69.84, p < 0.001; Bonferroni inequality, all p < 0.002) except 1997 and 1999 (Bonferroni inequality, p > 0.999). The mean monthly upwelling anomaly for June to August explained $80 \%$ of variation among years in the mean distance to nesting flyways (Fig. 8). Birds were closer to nesting flyways in years with higher bathymetry (Schneider et al. 1990) may also cause localized upwellings and development of prey aggregations (Cairns \& Schneider 1990, Bakun 1996). This study revealed that short-term variability in upwelling intensity and prey availability on the scale of days and weeks elicited a rapid response in the foraging behavior and habitat selection of this nearshore seabird.

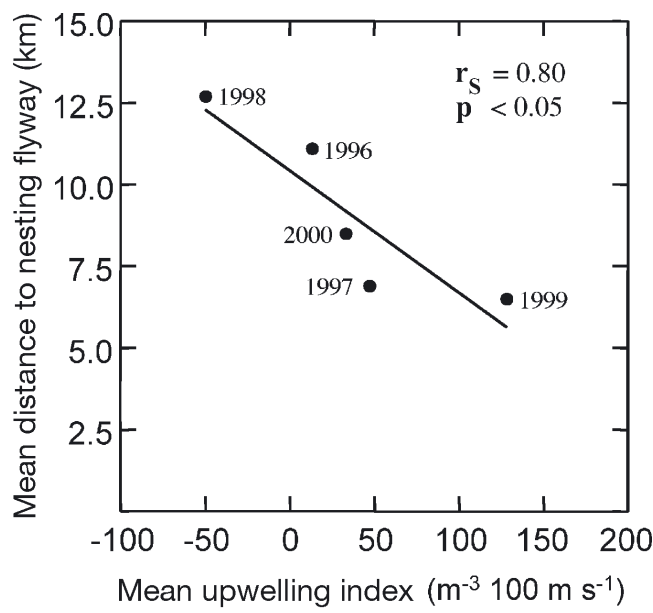

Fig. 8. Mean distance to nesting flyways versus mean June to August upwelling anomaly as a function of year 


\section{Effects of upwelling and prey availability on marbled murrelet distribution}

Upwelling along the California coast generates conditions that should be beneficial to foraging seabirds. Specifically, upwelling appears to increase the number and/or gradients of horizontal surface fronts that may aggregate prey (Fig. 2 and Bjorkstedt et al. 2002) and cause aggregative responses of other seabird prey at higher trophic levels, such as fishes. Similarly, upwelling creates a larger area of cool surface water that is generally higher in nutrients and phytoplankton (Bakun 1996). For example, Bjorkstedt et al. (2002) found elevated densities of juvenile rockfishes in patches situated along horizontal surface fronts. So, upwelling conditions create aggregations of prey that can be profitably exploited, reducing the likelihood that murrelets will need to travel large distances to satisfy their energetic requirements. Therefore, during low upwelling, there is limited high quality foraging habitat, and murrelets must fly farther to the limited sites of cool, recently upwelled waters to find adequate prey. During low upwelling, cool water patches may be remnants from previous upwelling events and may be more likely to have a rich local food web based on recent nutrient input (Bakun 1996).

Murrelets redistributed themselves closer to the nesting habitat only when both upwelling and prey availability were high (Fig. 3). Coyle et al. (1992) also found that common murres were only associated with prey when foraging within or near a front. These findings support the hypothesis that the interaction between oceanographic processes that aggregate prey and the overall abundance of prey can create conditions that are profitable for foraging seabirds. Only under such conditions are adequate prey densities likely to aggregate in identifiable and exploitable patches. When prey is relatively abundant but upwelling is low, prey may be either too dispersed to efficiently exploit or too difficult to locate due to lack of detectable oceanographic features (water temperature or visible surface fronts) for birds to use as cues.

Daily differences in mean distances from the nesting habitat to murrelet locations were relatively small (from 3.0 to $5.7 \mathrm{~km}$ : Fig. 3) for a seabird capable of flying more than $60 \mathrm{~km} \mathrm{~h}^{-1}$ and up to $90 \mathrm{~km}$ inland to nest (Ralph et al. 1995). For example, Whitworth et al. (2001) found that marbled murrelets in Alaska traveled a mean of $78 \mathrm{~km}$ between nesting and feeding areas. However, this pattern suggests that changes in the daily distribution of murrelets may be explained by competing constraints of obtaining adequate prey and minimizing flight costs. This pattern is also exhibited by several other seabird species. For example, common murres and rhinoceros auklets (Cerorhinca monocerata) disperse over larger areas in years when prey is less available and more dispersed (Burger \& Piatt 1990, Davoren 2000). Common murres, razorbills Alca torda, and Atlantic puffins Fratercula arctica also tend to remain closer to colonies when food is more abundant (Wanless et al. 1990).

\section{Nested effects of spatial scale on habitat selection}

Classification trees revealed spatially scaled and nested habitat selection by marbled murrelets. During low upwelling and low prey availability (LL), most birds responded to mesoscale features of cooler water close to the nesting habitat, but those that were in warmer waters or far from the nesting habitat, selected fine-scale fish schools (Fig. 4A). Fish schools are patchy over large areas, while SST and distance to nesting habitat are by nature highly autocorrelated and manifest their effects over a larger area. During low upwelling and high prey availability (LH: Fig. 4B), most birds selected cooler waters or were close to flyways. Nested within those conditions, there was a lesser degree of fine-scale selection for surface fronts. Fronts are much smaller and less autocorrelated over mesoscales than SSTs or distance to nesting habitat. This suggests that murrelet habitat selection is driven primarily by variability in nesting distance and SST, and that murrelets also exhibit fine-scale association with prey within frontal zones during periods of high prey availability. An alternative hypothesis regarding this association is that during high upwelling conditions, high winds cause surface mixing, breaking down finescale water structure and dispersing lower trophic-level organisms (Bakun 1996). In the absence of fine-scale water structure and related aggregations of prey, murrelets may be more apt to cue on larger surface fronts that are less likely to be dispersed during windy conditions.

The increased importance of fish schools at the fine-scale of $<10 \mathrm{~km}$ in a region of high prey abundance implies that murrelets make fine-scale decisions to associate with prey and mesoscale decisions to search for particular habitat types (SST or distance from nesting habitat). Some researchers (Hunt et al. 1999) have suggested that during low prey availability, seabirds may be more likely to be associated with prey patches, since it would be beneficial to stay with a prey patch when locating others is costly. Our results do not completely support this hypothesis, as murrelet-fish associations were only significant at fine-scales for the high prey availability surveys. However, significant murrelet-prey associations did occur during low upwelling and low prey availability (Fig. 4A), which does support the 'stay on prey patch' hypothesis.

Ostrand et al. (1998) also found a positive relationship between marbled murrelet and prey distribution 
in Prince William Sound, Alaska, where birds selected small, dense fish schools in shallow waters that were associated with stratified water. The oceanography of Prince William Sound has fewer potential prey-aggregating mechanisms than the highly dynamic California Current, and may be similar to California waters when upwelling is low or relaxed. When upwelling relaxes, California water quickly becomes vertically stratified (Bakun 1996) similar to the dominant setting in Prince William Sound. Marbled murrelets may forage in the temporarily vertically stratified California Current in a similar manner to the waters of Prince William Sound. The mesoscale low upwelling and low prey availability model (LL) supports this idea, as murrelets in warmer and presumably stratified water were associated with fishes (Fig. 4A). While the fine-scale results showed murrelet-fish associations whenever prey availability was high, direct spatial associations were more important when upwelling was low and water was more stratified (Fig. 6B).

Fine-scale associations between seabirds and their prey have received intensive study, but there is little consensus on the frequency or spatial scale of such associations (Swartzman \& Hunt 2000). Murrelet-prey associations probably occur more frequently than found in this study, since the sonar only detected potential prey directly beneath the boat and we encountered murrelets up to $150 \mathrm{~m}$ from the vessel. The high murrelet-fish association that occurred when we considered only murrelets within $25 \mathrm{~m}$ of the survey vessel supports this interpretation.

Studies of the relationship between seabird prey patchiness and predator-prey spatial associations have revealed that at larger scales, predator-prey associations increase with both increasing prey patchiness and abundance (Fauchald \& Erikstad 2002). Conversely, at small scales, associations increase with an increase in patchiness alone. While we did not quantify the patchiness of potential prey, the ability of prey to explain murrelet distribution was much less important at larger scales, and was very important and small scales when abundance was high. In our analyses, prey could only explain murrelet distribution if there were an association at the scale of less than $200 \mathrm{~m}$. Our small-scale results concur with those of Fauchald \& Erikstad (2002) in that predator-prey associations increased with prey abundance. However, patchiness at the mesoscale (prey patchiness should increase with upwelling) showed no affect on predatorprey associations.

\section{Temporal variation in mesoscale habitat selection}

While the habitat selection models showed no significant differences in mesoscale selection between 1999 and 2000, or fine-scale differences from 1998 to 2000, murrelets did show interannual variation in mesoscale distribution from 1996 to 2000 that also appear to be explained by variation in oceanography and prey availability. Murrelets were distributed farther from the 2 primary breeding area flyways during the 1998 ENSO event (Fig. 7). Based on murrelet and sonar surveys from 1998 to 2000, prey was generally less available during 1998, and population level reproductive success was significantly lower than in other years (Becker 2001). National Marine Fisheries Service trawls from 1996 to 2000 found the lowest numbers of squid, krill, and juvenile rockfish during the spring of 1998 (Becker 2001). Furthermore, during April to June 1998, central California had below-average upwelling (0 to 2 SDs below average) and mean monthly SSTs were 1.0 to $1.5^{\circ} \mathrm{C}$ above average. These ENSO effects reduce primary productivity and prey availability (Bakun 1996). With the breeding constraint relaxed and prey more difficult to obtain, we expect murrelets would on average forage farther from the nesting habitat during ENSO years. Murrelets were also farther from nesting habitat during June to August 1996. In this year, the upwelling index was 0.5 to $1 \mathrm{SD}$ below normal from March to May, but did increase with cooler water temperatures in June. This suggests a delayed spring transition in 1996, which may have forced some murrelets to forego breeding. However, the population level reproductive success in 1996 was similar to that in 1997, 1999 and 2000, indicating the ability of some seabirds to maintain adequate prey delivery to chicks when food is more dispersed (Davoren 2000).

Understanding seabird responses to rapidly varying foraging conditions that regulate seabird behavior and reproductive success may help identify processes that contribute to population declines, whether the threats are from factors at the nesting sites (predators, habitat loss) or at sea (lack of sufficient prey resources). The marbled murrelet's highly predictable response to variation in upwelling conditions and prey availability indicates that this population must rapidly change foraging strategies and distribution to exploit limited prey resources. This suggests that both short- and longterm oceanographic variation may, in addition to loss of nesting habitat, regulate this small population of seabirds.

Acknowledgements. We thank J. Ames, S. Sovndal, J. Sovndal, J. Holley, J. Lanser, M. Westphal, S. Hancock, L. Rachowicz, M. Cobleigh, K. Stevenson, J. Benson, N. Jones, Z. Peery, R. Seymour, R.C. Mitchell, T. Williamson, L. Espinoza, and H. Carter for aid with at-sea surveys. Z. Peery calculated upwelling-front correlations. Funding was provided by the Packard Foundation, University of California Berkeley, and the US Fish and Wildlife Service. Logistical support was provided by the California Dep- 
tartment of Fish and Game (J. Ames, D. Jessup, P. Kelly, and E. Burkett), Año Nuevo State Reserve (G. Strachan) and Big Creek Lumber Company (B. McCrary, Bulger family). J. Penvenne at Interphase Technologies provided sonar expertise. L. Henkel and S. Ralston provided the fish trawl data. J. Flint, E. Heaton, and M. Westphal gave advice on GIS and habitat modeling. Reviews by R. Barrett, M. Kelly, D. Penry, P. Jouventin and 3 anonymous reviewers improved this paper.

\section{LITERATURE CITED}

Ainley DG (1990) Farallon Seabirds: patterns at the community level. In: Ainley DG, Boekelheide RJ (eds) Seabirds of the Farallon Islands. Stanford University Press, Stanford, CA, p 349-382

Ainley DG, Boekelheide RJ (1990) (eds) Seabirds of the Farallon Islands. Stanford University Press, Stanford, CA

Ainley DG, Allen SG, Spear LB (1995a) Offshore occurrence patterns of Marbled Murrelets in Central California. In: Ralph CJ, Hunt GL, Raphael MG, Piatt JF (ed) Ecology and conservation of the Marbled Murrelet. Gen Tech Rep PSW-GTR-152, USDA Forest Service, Albany, CA, p 361-369

Ainley DG, Sydeman WJ, Norton J (1995b) Upper trophiclevel predators indicate interannual negative and positive anomalies in the California Current food web. Mar Ecol Prog Ser 118:69-79

Ainley DG, Spear LB, Allen SG (1996) Variation in the diet of Cassin's auklet reveals spatial, seasonal, and decadal occurrence patterns of euphausiids off California, USA. Mar Ecol Prog Ser 137:1-10

Bakun A (1996) Patterns in the ocean: ocean processes and marine population dynamics. California Sea Grant College System, National Oceanic and Atmospheric Administration (NOAA), La Jolla, CA

Becker BH (2001) Effects of oceanographic variation on Marbled Murrelet diet and habitat selection. PhD dissertation, University of California, Berkeley, CA

Becker BH, Beissinger SR, Carter HR (1997) At-sea density monitoring of marbled murrelets in central California: methodological considerations. Condor 99:743-755

Beissinger SR (1995) Population trends of the Marbled Murrelet projected from demographic analyses. In: Ralph CJ, Hunt GL, Raphael MG, Piatt JF (eds) Ecology and conservation of the Marbled Murrelet. Gen Tech Rep PSWGTR-152, USDA Forest Service, Albany, CA, p 385-394

Beissinger SR, Nur N (1997) Population trends of the Marbled Murrelet projected from demographic analyses. Recovery plan for the threatened Marbled Murrelet (Brachyramphus marmoratus) in Washington, Oregon, and California. US Fish and Wildlife Service, Portland, OR p B1-B52

Bjorkstedt EP, Rosenfeld LK, Grantham BA, Shkedy Y, Roughgarden J (2002) Distributions of larval rockfishes Sebastes spp. across nearshore fronts in a coastal upwelling region. Mar Ecol Prog Ser 242:215-228

Buckland ST, Anderson DR, Burnham KP, Laake JL (1993) Distance sampling: estimating the abundance of biological populations. Chapman \& Hall, London

Burger AE, Piatt JF (1990) Flexible time budgets in breeding Common Murres: buffers against variable prey abundance. Stud Avian Biol 14:71-83

Burkett EE (1995) Marbled Murrelet food habits and prey ecology. In: Ralph CJ, Hunt GL, Raphael MG, Piatt JF (eds) Ecology and conservation of the Marbled Murrelet. Gen Tech Rep PSW-GTR-152, USDA Forest Service, Albany, CA, p 223-246
Cairns DK, Schneider DC (1990) Hot spots in cold water: feeding habitat selection by Thick-billed Murres. Stud Avian Biol 14:61-66

Coyle KO, Hunt GL, Decker MB, Weingartner TJ (1992) Murre foraging, epibenthic sound scattering and tidal advection over a shoal near St. George Island, Bering Sea. Mar Ecol Prog Ser 83:1-14

Davoren GK (2000) Variability in foraging in response to changing prey distributions in rhinoceros auklets. Mar Ecol Prog Ser 198:283-291

De'ath G, Fabricius KE (2000) Classification and regression trees: a powerful yet simple technique for ecological data analysis. Ecology 81:3178-3192

Environmental Systems Research Institute (ESRI) (1998) ArcView GIS Version 3.2. ESRI, Redlands, CA

Fauchald P, Erikstad KE (2002) Scale-dependent predatorprey interactions: the aggregative response of seabirds to prey under variable prey abundance and patchiness. Mar Ecol Prog Ser 231:279-291

Fauchald P, Erikstad KE, Skarsfjord H (2000) Scale-dependent predator-prey interactions: the hierarchical spatial distribution of seabirds and prey. Ecology 81:773-783

Gaston AJ, Jones IL (1998) The Auks. Oxford University Press, Oxford

Hamer TE (1995) Inland habitat associations of marbled murrelets in Western Washington. In: Ralph CJ, Hunt GL Jr, Raphael MG, Piatt JF (eds) Ecology and conservation of the Marbled Murrelet. Gen Tech Rep PSW-GTR-152, USDA Forest Service, Albany, CA, p 163-175

Hoefer CJ (2000) Marine bird attraction to thermal fronts in the California current system. Condor 102:423-427

Hull CL, Kaiser GW, Lougheed C, Lougheed L, Boyd S, Cooke F (2001) Intraspecific variation in commuting distance of marbled murrelets (Brachyramphus marmoratus): ecological and energetic consequences of nesting further inland. Auk 118:1036-1046

Hunt GL (1997) Physics, zooplankton, and the distribution of Least Auklets in the Bering Sea - a review. ICES J Mar Sci 54:600-607

Hunt GL, Russell RW, Coyle KO, Weingartner T (1998) Comparative foraging ecology of planktivorous auklets in relation to ocean physics and prey availability. Mar Ecol Prog Ser 167:241-259

Hunt GL, Mehlum F, Russell RW, Irons D, Decker MB, Becker PH (1999) Physical processes, prey abundance, and the foraging ecology of seabirds. In: Adams NJ, Slotow RH (eds) Proc 22 Int Ornithol Congr, Durban. Birdlife South Africa, Johannesburg, p 2040-2056

Lachmann M, Sella G, Jablonka E (2000) On the advantages of information sharing. Proc R Soc Lond Ser B Biol Sci 267: $1287-1293$

Lougheed C (2000) Breeding chronology, breeding success, distribution and movement of marbled murrelets (Brachyramphus marmoratus) in Desolation Sound, British Columbia. Can Wildl Serv Tech Rep Ser 352:1-89

Nevitt G (1999) Olfactory foraging in Antarctic seabirds: a species-specific attraction to krill odors. Mar Ecol Prog Ser $177: 235-241$

Nevitt G, Veit R (1999) Mechanisms of prey-patch detection by foraging seabirds. In: Adams NJ, Slotow RH (eds) Proc 22 Int Ornithol Congr, Durban. Birdlife South Africa, Johannesburg, p 2072-2082

Orians GH, Pearson NE (1979) On the theory of central place foraging. In: Horn DJ, Mitchell RD, Stairs GR (eds) Analysis of ecological systems. Ohio State University Press, Columbus, OH, p 155-177

Ostrand WD, Coyle KO, Drew GS, Maniscalo JM, Irons DB 
(1998) Selection of forage fish schools by murrelets and Tufted Puffins in Prince William Sound, Alaska. Condor 100:286-297

Peery MZ, Beissinger SR, Newman S, Burkett E (2001) Marbled Murrelet telemetry in Central California. Pac Seabirds 28:48 (Abstract)

Piatt JF (1990) The aggregative response of Common Murres and Atlantic Puffins to schools of capelin. Stud Avian Biol 14:36-51

Ralph CJ, Hunt GL, Raphael MG, Piatt JF (1995) Ecology and conservation of the Marbled Murrelet in North America: an overview. In: Ralph CJ, Hunt GL, Raphael MG, Piatt JF (eds) Ecology and conservation of the Marbled Murrelet. Gen Tech Rep PSW-GTR-152, USDA Forest Service, Albany, CA, p 3-22

Ribic CA, Ainley DG (1997) The relationships of seabird assemblages to physical habitat features in Pacific equatorial waters during spring 1984-1991. ICES J Mar Sci 54: 593-599

Rosenfeld LK, Schwing FB, Garfield N, Tracy DE (1994) Bifurcated flow from an upwelling center: a cold water source for Monterey Bay. Contin Shelf Res 14:931-964

Russell RW, Hunt GL, Coyle CO, Cooney RT (1992) Foraging in a fractal environment: spatial patterns in a marine predator-prey system. Landsc Ecol 7:195-209

Russell RW, Harrison NM, Hunt GL (1999) Foraging at a front: hydrography, zooplankton, and avian planktivory in the northern Bering Sea. Mar Ecol Prog Ser 182:77-93

Safina C, Burger J (1988) Use of sonar and a small boat for studying foraging ecology of seabirds. Colon Waterbirds 11:234-244

Editorial responsibility: Otto Kinne (Editor),

Oldendorf/Luhe, Germany
Sakuma KM, Schwing FB, Pickett MH, Roberts D, Ralston S (2002) The physical oceanography off the central California coast during May-June 2000: a summary of CTD data from pelagic juvenile rockfish surveys. NOAA Techn Memo NMFS 318:1-83

SAS Institute Inc. (2000) JMP Version 4.02. SAS Institute Cary, NC

Schneider DC, Pierotti R, Threlfall W (1990) Alcid patchiness and flight direction near a colony in East Newfoundland. Stud Avian Biol 14:23-35

SPSS (1998) Systat 8.0 for Windows. SPSS, Chicago, IL

Swartzman G, Hunt G (2000) Spatial association between murres (Uria spp.), puffins (Fratercula spp.) and fish shoals near the Pribilof Islands, Alaska. Mar Ecol Prog Ser 206: 297-309

Verner J, Morrison ML, Ralph CJ (eds) (1986) Wildlife 2000: modeling habitat relati onships of terrestrial vertebrates. University of Wisconsin Press, Madison, WI

Wanless S, Harris MP, Morris JA (1990) A comparison of feeding areas used by individual Common Murres (Uria aalge), razorbills (Alca torda) and an Atlantic puffin (Fratercula arctica) during the breeding season. Colon Waterbirds 13: $16-24$

Weimerskirch H, Wilson RP, Lys P (1997) Activity pattern of foraging in the wandering albatross: a marine predator with two modes of prey searching. Mar Ecol Prog Ser 151: $245-254$

Whitworth DL, Nelson SK, Newman SH, Van Vliet GB, Smith W (2001) Foraging distances of radio-marked marbled murrelets from inland areas in southeast Alaska. Condor 102:452-456

Submitted: August 13, 2002; Accepted: March 23, 2003 Proofs received from author(s): June 30, 2003 